\title{
Recombinant Human Transforming Growth Factor-Alpha Stimulates the Formation of Osteoclast-like Cells in Long-term Human Marrow Cultures
}

\author{
N. Takahashi," B. R. MacDonald,“ J. Hon," M. E. Winkler,‡ R. Derynck,\$ G. R. Mundy," and G. D. Roodman* \\ *Veterans Administration Hospital, and "University of Texas Health Science Center, San Antonio, Texas 78284; and Departments of \\ $\ddagger$ Protein Biochemistry and §Molecular Biology, Genentech Inc., South San Francisco, California 94080
}

\begin{abstract}
Transforming growth factor-alpha (TGF- $\alpha$ ) is synthesized by a variety of tumor cell lines and stimulates osteoclastic bone resorption in vitro. The mechanism by which TGF- $\alpha$ increases osteoclast activity is unknown. We used a human marrow culture system that forms osteoclast-like multinucleated cells (MNCs) to determine the effects of recombinant human TGF- $\alpha$ on MNC formation. Addition of $0.01 \mathrm{ng} / \mathrm{ml}$ TGF- $\alpha$ for the 1 st week followed by 1,25-dihydroxyvitamin $D_{3}\left[1,25(\mathrm{OH})_{2} D_{3}\right]$ for the subsequent 2 wk significantly increased MNCs. Treatment of these cultures with TGF- $\alpha$ without later addition of $1,25(\mathrm{OH})_{2} \mathrm{D}_{3}$ did not increase MNC formation. Autoradiographic studies revealed that TGF- $\alpha$ stimulated proliferation of precursors for MNCs, and $1,25(\mathrm{OH})_{2} \mathrm{D}_{3}$ increased their rate of fusion into MNCs. Addition of murine epidermal growth factor (EGF) $(0.1 \mathrm{ng} / \mathrm{ml})$ followed by $1,25(\mathrm{OH})_{2} \mathrm{D}_{3}$ also significantly stimulated MNC formation. These data suggest that TGF- $\alpha$ and EGF may stimulate bone resorption by increasing the proliferation of osteoclast precursors, which leads to increased numbers of osteoclasts.
\end{abstract}

\section{Introduction}

Transforming growth factors are a heterogeneous family of polypeptides that reversibly induce anchorage-independent growth in nonneoplastic anchorage-dependent cells (1). One group, defined as $\alpha$-type, or transforming growth factor-alpha (TGF- $\alpha),{ }^{1}$ competes with epidermal growth factor (EGF) for binding to the same receptor and induces several known biological effects of EGF (2). TGF- $\alpha$ was first demonstrated in the conditioned medium of virally transformed neoplastic mouse cells (3), and has been purified from virally transformed rat cells and from human melanoma cell lines $(4,5)$. Recent developments have led to the cloning of a sequence coding for both human (6) and rat (7) TGF- $\alpha$, and to the production of a biologically active human TGF- $\alpha$ in Escherichia coli (6). Specific hybridizations have indicated that TGF- $\alpha$ messenger RNA (mRNA) is present in a variety of tumors, many of which can

Address correspondence to Dr. Roodman, Research Service (151), Audie Murphy Memorial Veterans Administration Hospital, 7400 Merton Minter Blvd., San Antonio, TX 78284.

Received for publication 10 February 1986 and in revised form 23 June 1986.

1. Abbreviations used in this paper: CFU-GM, granulocyte-macrophage colony-forming unit; CSF, colony stimulating factor, CSF-GM, granulocyte-macrophage CSF; $1,25(\mathrm{OH})_{2} \mathrm{D}_{3}, 1,25$-dihydroxyvitamin $\mathrm{D}_{3}$; EGF, epidermal growth factor; MEM, minimum essential medium; MNC, multinucleated cell; PCM, placental conditioned medium; TGF- $\alpha$, transforming growth factor-alpha.

The Journal of Clinical Investigation, Inc.

Volume 78, October 1986, 894-898 cause malignancy-associated hypercalcemia (Derynck, R., unpublished results).

Recently, both synthetic rat (8) and recombinant human TGF- $\alpha$ have stimulated osteoclastic bone resorption in vitro (911). Attention, therefore, has been focused on TGF- $\alpha$ as a possible mediator of increased bone resorption in the humoral hypercalcemia of malignancy (12-15). However, the underlying mechanism responsible for TGF- $\alpha$-induced osteoclastic bone resorption is unknown.

We recently developed a system for examining formation of osteoclast-like multinucleated cells (MNCs) from feline (16), baboon (17), and human bone marrow cells (MacDonald, B. R., N. Takahashi, L. M. McManus, G. R. Mundy, and G. D. Roodman, submitted for publication) in long-term cultures. The formation of MNCs was increased by parathyroid hormone and 1,25-dihydroxyvitamin $\mathrm{D}_{3}\left[1,25(\mathrm{OH})_{2} \mathrm{D}_{3}\right]$ and decreased by calcitonin. The MNCs contained a tartrate-resistant acid phosphatase, which is a marker enzyme for osteoclasts whose activity was modulated appropriately by osteotropic hormones $(16,17)$.

In this report, we examined the effects of recombinant human TGF- $\alpha$ and purified murine EGF on the MNC formation in human marrow long-term culture. We now report that TGF- $\alpha$ stimulates the formation of MNCs with osteoclast-like characteristics by increasing the proliferation of the precursors for these cells.

\section{Methods}

Collection and culture of human marrow cells. After obtaining informed consent, bone marrow was aspirated from the iliac crest of healthy normal donors. Marrow aspirates were collected in syringes containing 1,000 $\mathrm{U} / \mathrm{ml}$ preservative-free heparin (Sigma Chemical Co., St. Louis, MO) in alpha minimum essential medium (MEM) (Gibco, Grand Island, NY). Marrow mononuclear cells were obtained by centrifugation on HypaqueFicoll gradients as described previously (17). The cells were washed twice with alpha MEM and cultured in alpha MEM containing 20\% horse serum (Flow Laboratories, McLean, VA) at $10^{6}$ cells $/ \mathrm{ml}$ in 24-well plates (Linbro; Flow Laboratories) $(0.5 \mathrm{ml} /$ well). All cultures were maintained in a humidified atmosphere of $4 \% \mathrm{CO}_{2}$-air at $37^{\circ} \mathrm{C}$ for $3 \mathrm{wk}$. Cultures were fed weekly by removing half of the medium and replacing an equal volume of fresh medium (unless otherwise noted in the text). Murine EGF (receptor grade, $99 \%$ pure by sodium dodecyl sulfate-polyacrylamide gel electrophoresis; Collaborative Research, Inc., Waltham, MA) or recombinant human TGF- $\alpha$ was added to the cultures at varying concentrations for the first week or for the entire three weeks of culture. In selected experiments, $1,25(\mathrm{OH})_{2} \mathrm{D}_{3}$ (generously provided by $\mathrm{Dr}$. Uskokovic, Hoffman-LaRoche Inc., Nutley, $\mathrm{NJ}$ ) at a concentration of $10^{-8}$ $\mathrm{M}$, was added to the cultures. After $3 \mathrm{wk}$, cells were fixed with $5 \%$ glutaraldehyde (Sigma Chemical Co.), stained with Wright's stain, and cells containing three or more nuclei were counted with an inverted-phase microscope. Recombinant human TGF- $\alpha$ was expressed in $E$. coli as previously described (6). The protein was purified to homogeneity using Sephadex G-75 gel filtration and reverse-phase high performance liquid chromatography, and was $>99 \%$ pure as assessed by amino acid composition and high performance liquid chromatography. Mink CCL 64 
lung fibroblasts and UMR 106 osteosarcoma cells were used to verify the equivalence of TGF- $\alpha$ and murine EGF preparations $(6,9)$. Concentrations of TGF- $\alpha$ in terms of nanogram equivalents of EGF were measured by determining the amounts of TGF- $\alpha$ required to displace labeled EGF from its receptors $(6,9)$. Results are expressed as the mean \pm SEM for triplicate or quadruplicate samples. Statistical significance was evaluated using a Student's $t$ test for paired samples.

Autoradiography. Marrow cells were cultured in the presence or absence of $0.1 \mathrm{ng} / \mathrm{ml}$ of TGF- $\alpha$ or $10 \mathrm{ng} / \mathrm{ml}$ of EGF on Lux $15-\mathrm{mm}$ diam coverslips (Miles Laboratories, Waperville, IL). After $24 \mathrm{~h},\left[{ }^{3} \mathrm{H}\right]$ thymidine (0.5 $\mu \mathrm{Ci} /$ well) ( $59 \mathrm{Ci} / \mathrm{mmol} \mathrm{sp} \mathrm{act;} \mathrm{Schwartz} \mathrm{Mann,} \mathrm{Orangeburg,} \mathrm{NY)}$ was added for the next $48 \mathrm{~h}$. The medium was then removed and the fresh medium was added to the culture. Nonadherent cells removed with the spent medium were recovered by centrifugation and replaced with fresh medium. The cells were then cultured in the presence or absence of TGF- $\alpha$ or EGF for the next $4 \mathrm{~d}$. After 1 wk of culture the medium was replaced with fresh medium and the cultures continued for $2 \mathrm{wk}$ in the presence or absence of $1,25(\mathrm{OH})_{2} \mathrm{D}_{3}\left(10^{-8} \mathrm{M}\right)$. The cells were then fixed in 5\% glutaraldehyde for $15 \mathrm{~min}$, and following this the coverslips were mounted on glass slides and processed for autoradiography as described by Roodman et al. (18). Results are expressed as the percentage of MNCs containing one or more labeled nuclei, and also as the number of labeled nuclei per MNC (assessed from the first 100 MNCs). MNCs that formed on coverslips were also counted.

Assay of colony stimulating factor (CSF) activity. Bone marrow mononuclear cells were prepared as described above. $1 \times 10^{5}$ cells $/ \mathrm{ml}$ were then cultured in alpha MEM-20\% fetal calf serum in methylcellulose as described by Richman et al. (19) in the presence or absence of human placental conditioned medium (PCM) as a source of a CSF. In selected experiments varying concentrations of TGF- $\alpha$ were added to these cultures in the presence or absence of PCM. Marrow cells were cultured for 7 or $14 \mathrm{~d}$. Granulocyte-macrophage colony-forming unit (CFU-GM)derived colonies were then scored in situ using an inverted-phase microscope at the end of the culture period. Colonies were counted if they contained 40 or more cells per colony. In selected experiments, random colonies were plucked from the cultures with a finely drawn pipette, transferred to glass slides, and stained with Wright's stain to confirm that colonies were composed of granulocytes and monocytes-macrophages. Maximal colony formation occurs in these assays with $10 \% \mathrm{vol} /$ vol of PCM.

\section{Results}

The effects of recombinant human TGF- $\alpha$ on formation of osteoclast-like MNC are shown in Table I. As we have previously reported, treatment of marrow cells with $1,25(\mathrm{OH})_{2} \mathrm{D}_{3}\left(10^{-8} \mathrm{M}\right)$ for 3 wk markedly increased the number of MNCs (Table I). Treatment of the cultures for only the last 2 wk with $1,25(\mathrm{OH})_{2} \mathrm{D}_{3}$ significantly increased MNC formation in two of three experiments. Addition of $0.1 \mathrm{ng} / \mathrm{ml} \mathrm{TGF}-\alpha$ to the cultures for the first week or for all three weeks of culture did not significantly increase the number of MNCs. However, addition of TGF- $\alpha$ for the first week followed by treatment with $10^{-8} \mathrm{M} 1,25(\mathrm{OH})_{2} \mathrm{D}_{3}$ for the last two weeks of culture significantly increased the number of MNCs compared with corresponding control cultures treated with $1,25(\mathrm{OH})_{2} \mathrm{D}_{3}$ alone for the last two weeks $(P<0.01)$ (Table I).

The effects of adding varying concentrations of TGF- $\alpha$ to the cultures for 1 wk followed by $1,25(\mathrm{OH})_{2} \mathrm{D}_{3}\left(10^{-8} \mathrm{M}\right)$ for the final 2 wk of culture are shown in Table II. Addition of TGF- $\alpha$ at $0.001-10 \mathrm{ng} / \mathrm{ml}$ to the culture for $3 \mathrm{wk}$ did not change basal MNC formation (data not shown). Treatment of cultures with TGF- $\alpha$ at concentrations as low as $0.01 \mathrm{ng} / \mathrm{ml}$ for the first week followed by treatment with $1,25(\mathrm{OH})_{2} \mathrm{D}_{3}\left(10^{-8} \mathrm{M}\right)$ for the subsequent two weeks significantly increased the number of MNCs.
Table I. Effect of TGF- $\alpha$ on MNC Formation in Human Marrow Long-term Culture

\begin{tabular}{lllccl}
\hline Treatment & & \multicolumn{3}{l}{ MNC per culture } \\
\cline { 1 - 1 } \cline { 5 - 6 } Week 1 & Weeks 2 and 3 & & Exp. 1 & Exp. 2 & Exp. 3 \\
\hline Medium & Medium & & $1 \pm 0.5$ & $1 \pm 0.3$ & $129 \pm 10$ \\
$1,25(\mathrm{OH})_{2} \mathrm{D}_{3}$ & $1,25(\mathrm{OH})_{2} \mathrm{D}_{3}$ & & $11 \pm 5^{*}$ & $105 \pm 5 \ddagger$ & $498 \pm 92 \ddagger$ \\
Medium & $1,25(\mathrm{OH})_{2} \mathrm{D}_{3}$ & & $17 \pm 3 \ddagger$ & $49 \pm 5 \ddagger$ & $141 \pm 13$ \\
TGF- $\alpha$ & TGF- $\alpha$ & & $2 \pm 1$ & ND & $120 \pm 17$ \\
TGF- $\alpha$ & Medium & & $2 \pm 1$ & $6 \pm 1 \ddagger$ & $123 \pm 42$ \\
TGF- $\alpha$ & $1,25(\mathrm{OH})_{2} \mathrm{D}_{3}$ & & $28 \pm 3 \ddagger \S$ & $93 \pm 5 \ddagger \S$ & $319 \pm 43 \ddagger \S$ \\
& & & & & \\
\hline
\end{tabular}

Human bone marrow mononuclear cells $\left(5 \times 10^{5}\right.$ cells/well) were cultured in alpha MEM with $20 \%$ horse serum, in the presence or absence of TGF- $\alpha(0.1 \mathrm{ng} / \mathrm{ml})$ or $1,25(\mathrm{OH})_{2} \mathrm{D}_{3}\left(10^{-8} \mathrm{M}\right)$. After $3 \mathrm{wk}$ of culture, cells were fixed and stained with Wright's stain. Cells containing three or more nuclei per cell were scored. Results are expressed as means \pm SEM for three or four cultures. ND, not determined.

* Significantly different from control cultures (medium alone), $P<0.05$.

‡ Significantly different from control cultures (medium alone), $P<0.01$.

§ Significantly different from cultures treated with $1,25(\mathrm{OH})_{2} \mathrm{D}_{3}$ for the last $2 \mathrm{wk}, P<0.01$.

Maximal MNC formation occurred in two of three experiments when $0.1 \mathrm{ng} / \mathrm{ml}$ TGF- $\alpha$ was added to the cultures (Table II). The total number of adherent cells per culture was not changed by treatment of the cultures with TGF- $\alpha$ (control $=6,996 \pm 523$ adherent cells; $0.1 \mathrm{ng} / \mathrm{ml}$ TGF- $\alpha=6,831 \pm 396$ adherent cells).

Because the biological effects of TGF- $\alpha$ are mediated through EGF receptors, and EGF also stimulates osteoclastic bone resorption $(20,21)$, we next examined the effects of EGF on MNC formation (Table III). Addition of EGF alone $(0.01-50 \mathrm{ng} / \mathrm{ml})$ to the cultures for $3 \mathrm{wk}$ did not increase the number of MNCs

Table II. Effect of Varying Concentrations of TGF- $\alpha$ on MNC Formation

\begin{tabular}{llllll}
\hline Treatment & & \multicolumn{2}{l}{ MNC per culture } \\
\cline { 1 - 2 } \cline { 5 - 6 } Week 1 & Weeks 2 and 3 & & Exp. 1 & Exp. 2 & Exp. 3 \\
\hline Medium & $1,25(\mathrm{OH})_{2} \mathrm{D}_{3}$ & & $17 \pm 3$ & $49 \pm 5$ & $141 \pm 13$ \\
TGF- $\alpha(0.001 \mathrm{ng} / \mathrm{ml})$ & $1,25(\mathrm{OH})_{2} \mathrm{D}_{3}$ & & ND & $45 \pm 4$ & $184 \pm 26$ \\
TGF- $\alpha(0.01 \mathrm{ng} / \mathrm{ml})$ & $1,25(\mathrm{OH})_{2} \mathrm{D}_{3}$ & & $55 \pm 2^{*}$ & $65 \pm 2^{*}$ & $253 \pm 30^{*}$ \\
TGF- $\alpha(0.1 \mathrm{ng} / \mathrm{ml})$ & $1,25(\mathrm{OH})_{2} \mathrm{D}_{3}$ & & $28 \pm 3^{*}$ & $93 \pm 5^{*}$ & $319 \pm 43^{*}$ \\
TGF- $\alpha(1 \mathrm{ng} / \mathrm{ml})$ & $1,25(\mathrm{OH})_{2} \mathrm{D}_{3}$ & & $14 \pm 1$ & $44 \pm 7$ & $284 \pm 25^{*}$ \\
TGF- $\alpha(10 \mathrm{ng} / \mathrm{ml})$ & $1,25(\mathrm{OH})_{2} \mathrm{D}_{3}$ & $11 \pm 1$ & $8 \pm 3$ & $212 \pm 16 \ddagger$ \\
& & & & &
\end{tabular}

Human bone marrow mononuclear cells $\left(5 \times 10^{5}\right.$ cells/well) were cultured in the presence or absence of varying concentrations of TGF- $\alpha$ for 1 wk followed by treatment with $1,25(\mathrm{OH})_{2} \mathrm{D}_{3}\left(10^{-8} \mathrm{M}\right)$ for the next 2 wk. MNCs were counted after 3 wk of culture. Results are expressed as means \pm SEM for three or four cultures. ND, not determined.

* Significantly different from cultures treated with $1,25(\mathrm{OH})_{2} \mathrm{D}_{3}$ for the last $2 \mathrm{wk}, P<0.01$.

‡ Significantly different from cultures treated with $1,25(\mathrm{OH})_{2} \mathrm{D}_{3}$ for the last $2 \mathrm{wk}, P<0.05$. 
formed (data not shown). Treatment of marrow cells with EGF $(0.1-50 \mathrm{ng} / \mathrm{ml})$ for the first week followed by $1,25(\mathrm{OH})_{2} \mathrm{D}_{3}\left(10^{-8}\right.$ M) for the last two weeks significantly stimulated MNC formation (Table III). Maximal MNC formation in response to EGF was observed at concentrations of $10 \mathrm{ng} / \mathrm{ml}$. Treatment of the cultures with EGF did not change the total number of adherent cells per culture after 3 wk of culture (control $=9,372 \pm 1,650$ adherent cells; $10 \mathrm{ng} / \mathrm{ml}$ EGF = 9,240 $\pm 1,056$ adherent cells). In contrast to TGF- $\alpha$ and EGF, addition of other growth factors such as fibroblast growth factor $(0.5-50 \mathrm{ng} / \mathrm{ml}$, Collaborative Research, Inc.), platelet-derived growth factor (0.1$10 \mathrm{ng} / \mathrm{ml}$, Collaborative Research, Inc.), or recombinant human insulinlike growth factor $(0.25-25 \mathrm{nM}$, Amgen Biologicals, Thousand Oaks, CA) to the cultures for the first week followed by $1,25(\mathrm{OH})_{2} \mathrm{D}_{3}$ at $10^{-8} \mathrm{M}$ for the next two weeks failed to stimulate MNC formation (data not shown).

Autoradiographic studies (Table IV) showed that treatment of cultures with $1,25(\mathrm{OH})_{2} \mathrm{D}_{3}\left(10^{-8} \mathrm{M}\right)$ for the last $2 \mathrm{wk}$ did not significantly increase the number of MNC formed on coverslips or the percentage of MNCs containing labeled nuclei. However, this treatment significantly increased the number of labeled nuclei in MNCs containing at least one labeled nucleus. Treatment of cultures with TGF- $\alpha(0.1 \mathrm{ng} / \mathrm{ml})$ alone for the first week did not affect these parameters. Addition of TGF- $\alpha$ for the first week followed by $1,25(\mathrm{OH})_{2} \mathrm{D}_{3}$ for the next two weeks markedly increased the number of MNCs on the coverslips as well as the percentage of MNCs containing labeled nuclei. In separate experiments, treatment of cultures with $1,25(\mathrm{OH})_{2} \mathrm{D}_{3}$ alone for all three weeks significantly increased the number of MNCs on coverslips but did not change the percentage of MNCs containing labeled nuclei (unpublished results). These results suggest that TGF- $\alpha$ stimulates the proliferation of precursors for the MNCs and $1,25(\mathrm{OH})_{2} \mathrm{D}_{3}$ increases the rate of fusion of the precursors into MNCs. EGF $(10 \mathrm{ng} / \mathrm{ml})$ stimulated MNC formation in a similar manner as TGF- $\alpha$ (Table IV). Similar results were seen in two other separate experiments.

Finally, we examined whether TGF- $\alpha$ preparations possessed

Table III. Effect of Varying Concentrations of EGF on MNC Formation

\begin{tabular}{lcccc}
\hline Treatment & & & \multicolumn{2}{c}{ MNC per culture } \\
\cline { 1 - 2 } \cline { 5 - 6 } Week 1 & Weeks 2 and 3 & & Exp. 1 & Exp. 2 \\
\hline Medium & $1,25(\mathrm{OH})_{2} \mathrm{D}_{3}$ & & $3+1$ & $15+1$ \\
EGF $(0.01 \mathrm{ng} / \mathrm{ml})$ & $1,25(\mathrm{OH})_{2} \mathrm{D}_{3}$ & & $\mathrm{ND}$ & $20+7$ \\
EGF $(0.1 \mathrm{ng} / \mathrm{ml})$ & $1,25(\mathrm{OH})_{2} \mathrm{D}_{3}$ & & $8+1^{*}$ & $32+4^{*}$ \\
EGF $(1 \mathrm{ng} / \mathrm{ml})$ & $1,25(\mathrm{OH})_{2} \mathrm{D}_{3}$ & & $16+3^{*}$ & $40+6^{*}$ \\
EGF $(10 \mathrm{ng} / \mathrm{ml})$ & $1,25(\mathrm{OH})_{2} \mathrm{D}_{3}$ & & $27+8^{*}$ & $90+19^{*}$ \\
EGF $(50 \mathrm{ng} / \mathrm{ml})$ & $1,25(\mathrm{OH})_{2} \mathrm{D}_{3}$ & & $\mathrm{ND}$ & $28+5 \ddagger$ \\
EGF $(100 \mathrm{ng} / \mathrm{ml})$ & $1,25(\mathrm{OH})_{2} \mathrm{D}_{3}$ & & $12+5$ & $\mathrm{ND}$ \\
\hline
\end{tabular}

Human bone marrow mononuclear cells $\left(5 \times 10^{5}\right.$ cells/well $)$ were cultured in the presence or absence of varying concentrations of EGF for 1 wk followed by treatment with $1,25(\mathrm{OH})_{2} \mathrm{D}_{3}\left(10^{-8} \mathrm{M}\right)$ for the next 2 wk. MNCs were counted after 3 wk of culture. Results are expressed as means \pm SEM for three or four cultures. ND, not determined. * Significantly different from cultures treated with $1,25(\mathrm{OH})_{2} \mathrm{D}_{3}$ for the last $2 \mathrm{wk}, P<0.01$.

$\ddagger$ Significantly different from cultures treated with $1,25(\mathrm{OH})_{2} \mathrm{D}_{3}$ for the last 2 wk, $P<0.05$.
Table IV. Autoradiography of MNCs Formed in Response to TGF- $\alpha$ and EGF

\begin{tabular}{|c|c|c|c|c|}
\hline \multicolumn{2}{|l|}{ Treatment } & \multirow{2}{*}{$\begin{array}{l}\text { MNCs/ } \\
\text { coverslip }\end{array}$} & \multirow{2}{*}{$\begin{array}{l}\text { Cells } \\
\text { containing } \\
\text { labeled nuclei }\end{array}$} & \multirow{2}{*}{$\begin{array}{l}\text { Labeled } \\
\text { nuclei/labeled } \\
\text { cell }\end{array}$} \\
\hline Week 1 & Weeks 2 and 3 & & & \\
\hline & & & $\%$ & \\
\hline Medium & Medium & $453 \pm 73$ & $12.0 \pm 2.3$ & $1.10 \pm 0.05$ \\
\hline Medium & $1,25(\mathrm{OH})_{2} \mathrm{D}_{3}$ & $568 \pm 110$ & $13.3 \pm 0.7$ & $1.37 \pm 0.07^{*}$ \\
\hline TGF- $\alpha$ & Medium & $446 \pm 91$ & $12.8 \pm 2.0$ & $1.16 \pm 0.06$ \\
\hline TGF- $\alpha$ & $1,25(\mathrm{OH})_{2} \mathrm{D}_{3}$ & $831 \pm 38^{*} \ddagger$ & $24.0 \pm 3.0^{*} . \S$ & $1.35 \pm 0.08^{*}$ \\
\hline EGF & Medium & $457 \pm 46$ & $15.3 \pm 1.8$ & $1.26 \pm 0.10$ \\
\hline EGF & $1,25(\mathrm{OH})_{2} \mathrm{D}_{3}$ & $806 \pm 28^{*} \ddagger$ & $24.0 \pm 2.5^{*} . \S$ & $1.60 \pm 0.19^{*}$ \\
\hline
\end{tabular}

Human bone marrow mononuclear cells $\left(5 \times 10^{5}\right.$ cells/well $)$ were cultured on the Lux coverslip in the presence or absence of TGF- $\alpha(0.1$ $\mathrm{ng} / \mathrm{ml})$, EGF $(10 \mathrm{ng} / \mathrm{ml})$, or $1,25(\mathrm{OH})_{2} \mathrm{D}_{3}\left(10^{-8} \mathrm{M}\right)$. After $24 \mathrm{~h}$ of culture, $\left[{ }^{3} \mathrm{H}\right]$ thymidine $(0.5 \mu \mathrm{Ci} /$ well $)$ was added for the next $48 \mathrm{~h}$. Cells were fixed after 3 wk of culture and processed for autoradiography. MNCs on coverslips and labeled nuclei in MNCs were scored. Results are expressed as means \pm SEM for three or four cultures.

* Significantly different from control cultures (medium alone), $P<0.01$.

$¥$ Significantly different from cultures treated with $1,25(\mathrm{OH})_{2} \mathrm{D}_{3}$ for the last $2 \mathrm{wk}, P<0.05$.

$\S$ Significantly different from cultures treated with $1,25(\mathrm{OH})_{2} \mathrm{D}_{3}$ for the last 2 wk, $P<0.01$.

granulocyte-macrophage colony stimulating factor (CSF-GM) activity because our previous studies showed that CSF-GM increased MNC formation when CSF-GM was added for the first week of culture followed by $1,25(\mathrm{OH})_{2} \mathrm{D}_{3}$ for the last two weeks of culture (22). In a standard marrow culture CSF assay, PCM at the concentrations of 1 or $10 \%$ markedly increased the number of colonies at 7 and $14 \mathrm{~d}$ of culture (Table V). TGF- $\alpha$ at $0.001-$

Table V. Effect of TGF- $\alpha$ on CFU-GM Assay

\begin{tabular}{|c|c|c|c|c|}
\hline \multirow[b]{3}{*}{ Treatment } & \multicolumn{4}{|c|}{ Colony formation } \\
\hline & \multicolumn{2}{|l|}{ Exp. 1} & \multicolumn{2}{|l|}{ Exp. 2} \\
\hline & Day 7 & Day 14 & Day 7 & Day 14 \\
\hline Medium & 0 & $1 \pm 0.2$ & 0 & $2 \pm 0.4$ \\
\hline PCM (1\%) & ND & ND & $47 \pm 3$ & $47 \pm 2$ \\
\hline PCM (10\%) & $35 \pm 2$ & $29 \pm 3$ & $94 \pm 2$ & $86 \pm 6$ \\
\hline TGF- $\alpha(0.001 / \mathrm{ng} / \mathrm{ml})$ & ND & ND & 0 & $1 \pm 0.6$ \\
\hline TGF- $\alpha(0.1 \mathrm{ng} / \mathrm{ml})$ & 0 & $3 \pm 0.3$ & 0 & $0.3 \pm 0.3$ \\
\hline TGF- $\alpha(10 \mathrm{ng} / \mathrm{ml})$ & 0 & $1 \pm 0.2$ & $1 \pm 0.5$ & 0 \\
\hline $\begin{array}{l}\mathrm{PCM}(1 \%)+\mathrm{TGF}-\alpha \\
(0.1 \mathrm{ng} / \mathrm{ml})\end{array}$ & ND & ND & $50 \pm 5$ & $27 \pm 0.2$ \\
\hline $\begin{array}{l}\text { PCM }(10 \%)+\text { TGF- } \alpha \\
(0.1 \mathrm{ng} / \mathrm{ml})\end{array}$ & ND & ND & $107 \pm 6$ & $81 \pm 6$ \\
\hline
\end{tabular}

Human bone marrow mononuclear cells $\left(5 \times 10^{4}\right.$ cells/well $)$ were cultured in alpha MEM with $20 \%$ fetal calf serum in methylcellulose, in the presence or absence of PCM as a CSF. In selected experiments, varying concentrations of TGF- $\alpha$ were added to cultures. CFU-GMderived colonies that are composed of $\mathbf{4 0}$ or more cells were counted. Results are expressed as means \pm SEM for three cultures. ND, not determined. 
$10 \mathrm{ng} / \mathrm{ml}$ did not stimulate colony formation. Furthermore, TGF- $\alpha(0.1 \mathrm{ng} / \mathrm{ml})$ did not affect colony formation stimulated by PCM (Table V, exp. 2). Colonies formed in these cultures were composed of granulocytes and monocytes-macrophages.

\section{Discussion}

We recently reported that osteoclast-like MNCs are formed in feline, baboon $(16,17)$, and human marrow long term cultures (MacDonald, B. R., N. Takahashi, L. M. McManus, G. R. Mundy, and G. D. Roodman, submitted for publication). These MNCs have several ultrastructural features of osteoclasts, respond appropriately to osteotropic hormones, and contain a tartrate-resistant acid phosphatase, a marker enzyme for osteoclasts. This long-term marrow culture system allows us to test the action of agents, which stimulate bone resorption and increase osteoclast numbers on formation of osteoclast-like cell in vitro. Using this culture system we can differentiate if these agents are increasing osteoclast numbers by increasing the number of precursor cells, increasing the rate of fusion of the precursors, or both.

In this report, we demonstrated that recombinant human TGF- $\alpha$ increased the number of osteoclast-like MNCs in longterm human marrow cultures when marrow cells were incubated with TGF- $\alpha$ for the first week followed by $1,25(\mathrm{OH})_{2} \mathrm{D}_{3}$ for two weeks. Autoradiographic studies demonstrated that TGF- $\alpha$ stimulated the proliferation of precursors of MNCs while $1,25(\mathrm{OH})_{2} \mathrm{D}_{3}$ stimulated the fusion of these precursors into MNCs. We previously reported that CSF increases the number of MNCs by stimulating proliferation of the precursors for these cells in baboon marrow cultures, and $1,25(\mathrm{OH})_{2} \mathrm{D}_{3}$ potentiated CSF effects by promoting fusion of the precursors (22). Thus, the action of TGF- $\alpha$ on MNC formation is similar to that of CSF. TGF- $\alpha$, however, had no CSF-like activity in a standard marrow culture CSF assay. This indicates that both TGF- $\alpha$ and CSF are able to enhance the proliferation of precursors for osteoclast-like cells. Possibly the action of TGF- $\alpha$ may be restricted to a committed osteoclast precursor, which may be a more differentiated progeny of CFU-GM, while CSF is acting on the less differentiated CFU-GM. In contrast to TGF- $\alpha$ and CSF, other growth factors such as fibroblast growth factor, platelet-derived growth factor, and insulinlike growth factor failed to stimulate MNC formation. This suggests that although these growth factors are mitogenic for many cell types, the stimulation of $\mathrm{MNC}$ formation appears to be a specific property of TGF- $\alpha$ and CSF.

EGF is known to be a potent stimulant of osteoclastic bone resorption $(20,21)$. In our experiments, EGF increased the number of osteoclast-like cells similar to TGF- $\alpha$. These results suggest that the bone-resorbing activity of EGF may result in part from the enhancement of proliferation of osteoclast precursors.

TGF- $\alpha$ has recently been implicated in the pathogenesis of the humoral hypercalcemia of malignancy $(14,15)$. This syndrome is thought to be caused by tumor cells releasing circulating factors that stimulate osteoclastic bone resorption $(14,15,23)$. Ibbotson et al. (12) first demonstrated that in the hypercalcemic variant of the rat Leydig cell tumor, TGF- $\alpha$-like activity was produced by the tumor cells and stimulated bone resorption in organ culture. The tumor-derived bone-resorbing activity was blocked by antisera to the EGF receptor (13). In addition, both synthetic rat (8) and recombinant human TGF- $\alpha$ have been shown to stimulate bone resorption in vitro (9-11). These observations indicate that TGF- $\alpha$ may be responsible for increased bone destruction in some neoplastic disease states.
Although many lines of evidence indicate that TGF- $\alpha$ is a tumor product in adult animal and human, TGF- $\alpha$ has also been found in increased amounts in developing rodent embryos (24). Recently, Smith et al. (25) reported that TGF- $\alpha$ accelerated eyelid opening on newborn mice and Tam (26) showed that TGF- $\alpha$ also accelerated incisor eruption in these animals. These results suggest that TGF- $\alpha$ could have physiological actions in the developing fetus and newborns. The effects of TGF- $\alpha$ on bone resorption and on the formation of osteoclast-like cells support the conclusion that TGF- $\alpha$ could play an important role in bone metabolism in both normal and pathologic states by stimulating the proliferation of osteoclast precursors. These results further suggest that the precursors for osteoclast-like cells are exquisitely sensitive to TGF- $\alpha$ and respond to TGF- $\alpha$ at much lower concentrations than those reported in other systems (8-12).

\section{Acknowledgments}

We wish to thank D. Hutzler and W. Montgomery for their excellent technical assistance, and J. Laderer for secretarial assistance.

This work was supported by research funds from the Veterans Administration, grant AM35188 from the National Institutes of Arthritis, Diabetes, Digestive and Kidney Diseases, HL-31264 from the Heart, Lung and Blood Institute, and CA-40035 from the National Cancer Institute.

\section{References}

1. Roberts, A. B., C. A. Frolik, M. A. Anzano, and M. B. Sporn. 1983. Transforming growth factors from neoplastic and nonneoplastic tissues. Fed. Proc. 42:2621-2625.

2. Massague, J. 1983. Epidermal growth factor-like transforming growth factor II. Interaction with epidermal growth factor receptors in human plancenta membranes and A431 cells. J. Biol. Chem. 258:1361413620.

3. DeLarco, J. E., and G. J. Todaro. 1978. Growth factors from murine sarcoma virus-transformed cells. Proc. Natl. Acad. Sci. USA. 75: 4001-4005.

4. Marquardt, H., M. W. Hunkapiller, L. E. Hood, D. R. Twardzik, J. E. DeLarco, J. R. Stephenson, and G. J. Todaro. 1983. Transforming growth factors produced by retrovirus-transformed rodent fibroblasts and human melanoma cells: amino acid sequence homology with epidermal growth factor. Proc. Natl. Acad. Sci. USA. 80:4684-4688.

5. Massague, J. 1983. Epidermal growth factor-like transforming growth factor I. Isolation, chemical characterization and potentiation by other transforming growth factors from feline sarcoma virus-transformed rat cells. J. Biol. Chem. 258:13606-13613.

6. Derynck, R., A. B. Roberts, M. E. Winkler, E. Y. Chen, and D. V. Goeddel. 1984. Human transforming growth factor- $\alpha$ : precursor structure and expression in E. coli. Cell. 38:287-297.

7. Lee, D. C., T. M. Rose, N. R. Webb, and G. J. Todaro. 1985. Cloning and sequence analysis of a cDNA for rat transforming growth factor- $\alpha$. Nature (Lond.). 313:489-491.

8. Ibbotson, K. J., D. R. Twardzik, S. M. D'Souza, W. R. Hargreaves, G. J. Todaro, and G. R. Mundy. 1985. Stimulation of bone resorption in vitro by synthetic transforming growth factor-alpha. Science (Wash. DC). 228:1007-1009.

9. Ibbotson, K. J., J. Harrod, M. Gowen, S. D'Souza, D. D. Smith, M. E. Winkler, R. Derynck, and G. R. Mundy. 1986. Human recombinant transforming growth factor alpha stimulates bone resorption and inhibits formation in vitro. Proc. Natl. Acad. Sci. USA. 83:2228-2232.

10. Tashjian, A. H., E. F. Voelkel, M. Lazzaro, F. R. Singer, A. B. Roberts, R. Derynck, M. E. Winkler, and L. Levine. 1985. $\alpha$ and $\beta$ human transforming growth factors stimulate prostaglandin production and bone resorption in cultured mouse calvaria. Proc. Natl. Acad. Sci. USA. 82:4535-4538. 
11. Stern, P. H., N. S. Krieger, R. A. Nissenson, R. D. Williams, M. E. Winkler, R. Derynck, and G. J. Strewler. 1985. Human transforming growth factor-alpha stimulates bone resorption in vitro. J. Clin. Invest. 76:2016-2019.

12. Ibbotson, K. J., S. M. D'Souza, K. W. Ng, C. K. Osborne, M. Niall, T. J. Martin, and G. R. Mundy. 1983. Tumor-derived growth factor increases bone resorption in a tumor associated with humoral hypercalcemia of malignancy. Science (Wash. DC). 221:1292-1294.

13. Ibbotson, K. J., S. M. D'Souza, D. D. Smith, C. Carpenter, and G. R. Mundy. 1985. EGF receptor antiserum inhibits bone resorbing activity produced by a rat Leydig cell tumor associated with the humoral hypercalcemia of malignancy. Endocrinology. 116:469-471.

14. Mundy, G. R., K. J. Ibbotson, S. M. D'Souza, E. L. Simpson, J. W. Jacobs, and T. J. Martin. 1984. The hypercalcemia of cancer: clinical implications and pathogenic mechanisms. N. Engl. J. Med. 310: 1718-1727.

15. Mundy, G. R., K. J. Ibbotson, and S. M. D'Souza. 1985. Tumor products and the hypercalcemia of malignancy. J. Clin. Invest. 76:391394.

16. Ibbotson, K. J., G. D. Roodman, L. M. McManus, and G. R. Mundy. 1984. Identification and characterization of osteoclast-like cells and their progenitors in cultures of feline marrow mononuclear cells. $J$. Cell Biol. 99:471-480.

17. Roodman, G. D., K. J. Ibbotson, B. R. MacDonald, T. J. Kuehl, and G. R. Mundy. 1985. 1,25-Dihydroxyvitamin $D_{3}$ causes formation of multinucleated cells with several osteoclast characteristics in cultures of primate marrow. Proc. Natl. Acad. Sci. USA. 82:8213-8217.

18. Roodman, G. D., J. J. Hutton, and F. J. Bollum. 1976. DNA polymerase, thymidine kinase and DNA synthesis in erythropoietic mouse spleen cells separated on bovine serum albumin gradients. Biochim. Biophys. Acta. 425:478-491.

19. Richman, C. W., L. Chess, and R. A. Yankee. 1978. Purification and characterization of granulocytic progenitor cells (CFU-c) from human peripheral blood using immunologic surface markers. Blood. 51:1-8.

20. Tashjian, A. H., and L. Levine. 1978. Epidermal growth factor stimulates prostaglandin production and bone resorption in cultured mouse calvaria. Biochem. Biophys. Res. Commun. 85:966-975.

21. Raisz, L. G., H. A. Simmons, A. L. Sandberg, and E. Canalis. 1980. Direct stimulation of bone resorption by epidermal growth factor. Endocrinology. 107:270-273.

22. MacDonald, B. R., G. R. Mundy, S. Clark, T. J. Kuehl, E. R. Standley, and G. D. Roodman. 1985. Effects of human recombinant CSF-GM and highly purified CSF-1 on the formation of multinucleated cells with osteoclast characteristics in long term bone marrow cultures. J. Bone Min. Res. 1:227-233.

23. Stewart, A. F., R. Horst, L. J. Deftos, E. C. Cadman, R. Lang, and A. E. Broadus. 1980. Biochemical evaluation of patients with cancerassociated hypercalcemia: evidence for humoral and nonhumoral groups. N. Engl. J. Med. 303:1377-1383.

24. Twardzik, D. R. 1985. Differential expression of transforming growth factor- $\alpha$ during prenatal development of the mouse. Cancer Res. 45:5413-5416.

25. Smith, J. M., M. B. Sporn, A. B. Roberts, R. Derynck, M. E. Winkler, and $\mathrm{H}$. Gregory. 1985. Human transforming growth factor- $\alpha$ causes precocious eyelid opening in newborn mice. Nature (Lond.). 315: 515-516.

26. Tam, J. P. 1985. Physiological effects of transforming growth factor in the newborn mouse. Science (Wash. DC). 229:673-675. 